Review

\title{
Current Advances of Tubulin Inhibitors in Nanoparticle Drug Delivery and Vascular Disruption/Angiogenesis
}

\author{
Souvik Banerjee ${ }^{\dagger}$, Dong-Jin Hwang ${ }^{\dagger}$, Wei Li ${ }^{*}$ and Duane D. Miller * \\ Department of Pharmaceutical Sciences, University of Tennessee Health Science Center, \\ 881 Madison Ave. Memphis, TN 38163, USA; sbanerj5@uthsc.edu (S.B.); dhwang@uthsc.edu (D.-J.H.) \\ * Correspondence: wli@uthsc.edu (W.L.); dmiller@uthsc.edu (D.D.M.); Tel.: +1-901-448-6026 (D.D.M.) \\ + These authors contributed equally.
}

Academic Editor: Derek J. McPhee

Received: 24 August 2016; Accepted: 27 October 2016; Published: 2 November 2016

\begin{abstract}
Extensive research over the last decade has resulted in a number of highly potent tubulin polymerization inhibitors acting either as microtubule stabilizing agents (MSAs) or microtubule destabilizing agents (MDAs). These inhibitors have potent cytotoxicity against a broad spectrum of human tumor cell lines. In addition to cytotoxicity, a number of these tubulin inhibitors have exhibited abilities to inhibit formation of new blood vessels as well as disrupt existing blood vessels. Tubulin inhibitors as a vascular disrupting agents (VDAs), mainly from the MDA family, induce rapid tumor vessel occlusion and massive tumor necrosis. Thus, tubulin inhibitors have become increasingly popular in the field of tumor vasculature. However, their pharmaceutical application is halted by a number of limitations including poor solubility and toxicity. Thus, recently, there has been considerable interests in the nanoparticle drug delivery of tubulin inhibitors to circumvent those limitations. This article reviews recent advances in nanoparticle based drug delivery for tubulin inhibitors as well as their tumor vasculature disruption properties.
\end{abstract}

Keywords: tubulin dynamics; tubulin inhibitors; multidrug resistance; nanoparticle formulations; $\beta$-tubulin isotypes and drug resistance; angiogenesis; vascular disrupting agent; antimitotic

\section{Introduction}

Since the discovery of the action of colchicine by Borisy et al. [1] in 1967, for the last 50 years, tubulin/microtubules have been long thought to be crucial chemotherapy targets in various cancer types, especially for breast, lung, ovarian and pancreatic carcinomas [2]. Microtubule-targeted agents (MTAs), including taxanes (e.g., paclitaxel (PTX)) and Vinca alkaloids (e.g., vinblastine) as shown in Figure 1, are considered to work primarily by increasing or decreasing the cellular microtubule mass. These effects play important roles in their chemotherapeutic actions to mitotic block and triggering apoptosis [2]. Additionally, while MTAs are mitotic inhibitors, recent findings suggest that anti-cancer properties of the MTAs may be attributed to their non-mitotic effects [3].

The microtubules are multifunctional cytoskeletal proteins, composed of $\alpha$ - and $\beta$-tubulin heterodimers [4], involved in many essential cell functions including maintenance of cell shape, intracellular transport, and in mitosis, functioning as part of the spindle to ensure proper chromosome segregation and cell division [5,6]. Microtubule-targeting agents can be divided into two main separated groups depending on their mechanisms of actions, microtubule-stabilizing (MSA) and microtubule destabilizing agents (MDA) [7]. MSAs prefers to bind to the polymerized tubulins and stabilize microtubules, while MDAs prefer to bind to the tubulin dimers and destabilize microtubules $[8,9]$. 


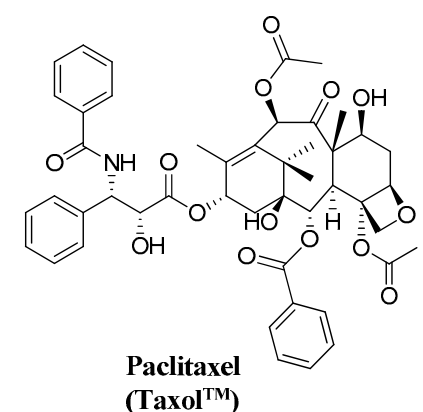

(Taxol $^{\mathrm{TM}}{ }^{\text {) }}$

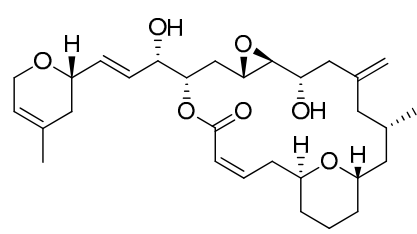

Laulimalide

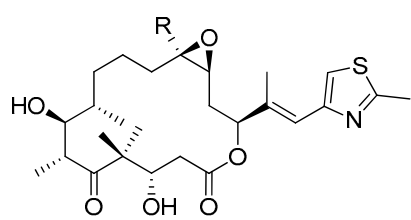

Epothilone A, R=H Epothilone B, R $=\mathrm{CH}_{3}$

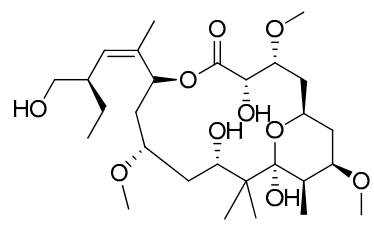

Peloruside A

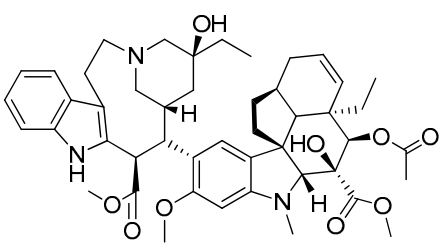

Vinca alkaloid (vinblastine)

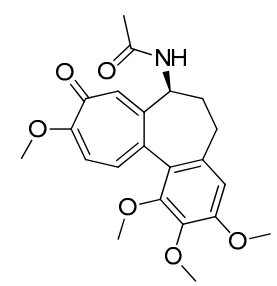

Colchicine

DESTABILIZING AGENTS

STABILIZING AGENTS

Figure 1. Chemical structures of representative natural products of microtubule stabilizing (MSA) and destabilizing agents (MDA).

During the last 20 years, many MSAs have entered the clinical trial stages and some of them have become effective anticancer drugs [7]. Most of these tubulin inhibitors were derived from natural products or their structural modified analogs. The anti-tubulin/anti-mitotic agents bind to one of the three best characterized binding sites on $\alpha$ - or $\beta$-tubulin subunits, which are the taxane, vinca alkaloids, and colchicine binding sites [10]. Recently, Prota et al. [11] reported the anti-tubulin mechanisms of laulimalide and peloruside A by X-ray crystallography. These two MSAs bind to a unique non-taxane site on $\beta$-tubulin using their respective macrolide core structures. It showed the agents/ligands interact with a second tubulin dimer across proto-filaments. And they allosterically stabilize the taxane-site M-loop that establishes lateral tubulin contacts in microtubules. The binding modes in each $\beta$-tubulin depicted in $\beta$ Tub1 and $\beta$ Tub2 at Figure 2. For MDA, vinca alkaloids, including vinblastine, vincristine, and vinorelbine, promote to protect polymerization of tubulin to destabilize microtubules' action. The vinca-binding domain on $\beta$-tubulin is located near the exchangeable GTP binding site [12]. To treat the patients with the solid tumors or hematologic malignancies, the vinca alkaloids have been used as single agents or in combination with other cytotoxic agents. And, as another destabilizer of MDA, colchicine has been focus on its dynamic instability as small molecules. Ravelli et al. [13] reported a complex of tubulin-colchicin vs. SLD (stathmin-like domain) and its tubulin regulation on crystallization study. It showed the colchicine bound to $\beta$-subunits at the interface with $\alpha$-tubulin. The complex includes two tubulin heterodimers, with colchicine bound to $\beta$-subunits at the interface with $\alpha$-subunit as summarized in Figure 2. For last few decades after a discovery of tubulin action, many microtubule inhibitors of MSAs and/or MDAs have been used for clinical activity to treat aggressive tumors based on their unique mechanisms of action. Some microtubule-targeted drugs can act as vascular-targeting agents $[14,15]$, rapidly depolymerizing microtubules of newly formed vasculature to shut down the blood supply to tumors [16]. 


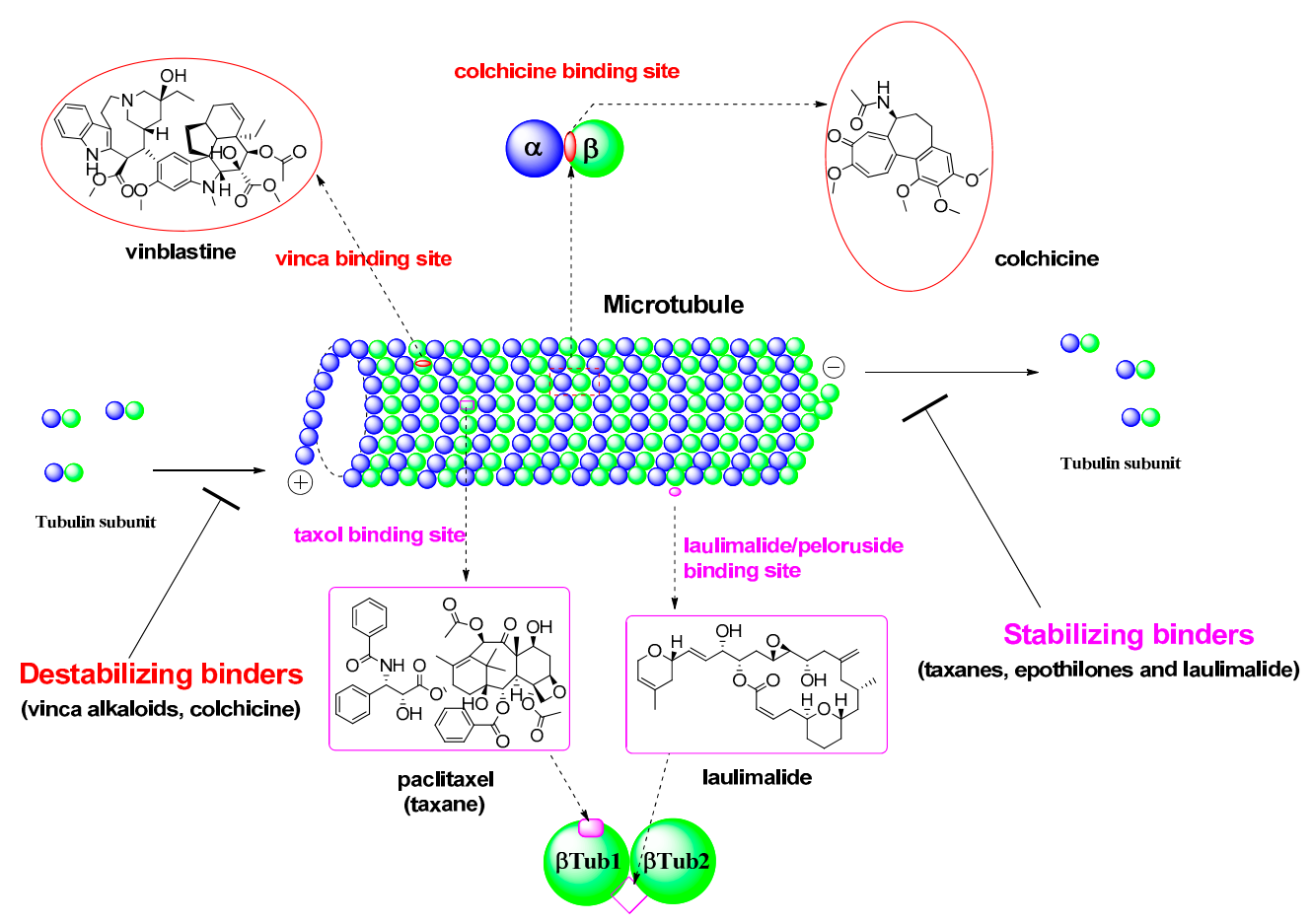

Figure 2. Tubulin binding sites and representative natural products of microtubule-targeted drugs.

Although antitubulin/antimitotic agents are widely used clinically, they have been facing a number of challenges, namely multidrug resistance (MDR) [17], low bioavailability, poor solubility, high toxicity [8], in their clinical trials. To overcome the barrier of current inconvenient for its treatment, a variety of studies have focused on improving the pharmaceutical properties of their agents. As followed our previous review about overview of colchicine binding agents [18], this review provides an overview of its nanoparticle drug delivery and angiogenesis of those microtubule-targeting drugs which are to date under clinical evaluation.

\section{Nanoparticle Delivery of Tubulin Inhibitors}

Recently, a number of research groups both from academia and industry have come up with a number of highly potent tubulin polymerization inhibitors with promising in vitro as well as in vivo efficacy [18-25]. However, the pharmaceutical development of most of the newly developed tubulin inhibitors is facing a number of obstacles, namely: (a) low solubility; (b) low bioavailability, as well as (c) high toxicity [26-29]. One of the possibilities to circumvent this obstacle is targeted delivery of the tubulin inhibitors to the cancer tissue [29]. There are a number of commonly used measures to targeted drug delivery including polymer conjugation and conjugation to antibodies that are upregulated in specific cancer cells [30-34]. In this context, nanoparticles or macromolecular carries have been observed to introduce positive changes in the pharmacokinetics as well as pharmacodynamics of the chemotherapeutics through a number of ways including: (a) improving solubility; (b) enhancing half-life by avoiding first pass kidney clearance; (c) greatly augmenting drug concentration in tumor cells by improved permeability and retention effect; as well as (d) saving the drug from enzymatic degradation $[26,28,29]$.

\subsection{Nano Particle Delivery of Tubulin Inhibitors Targeting Vinca Binding Site}

\subsubsection{Delivery of Tubulysine A (TubA)}

Recently, Schluep et al have reported the synthesis and evaluation both in vitro and in vivo of a nanoparticle prodrug of TubA [29]. Tubulysins are one of the naturally available tetrapeptides 
with highly potent cytotoxic activity against diverse cancer cell lines [29,35-41]. Tubulysins exert its biological effects by binding to the vinca site of tubulin receptor in a noncompetitive fashion [29,35-40]. Recent literature reports a few of articles with total synthesis and structure activity relationship of a number of tubulysin derivatives with equal or greater activity as compared to the naturally occurring tubulysin [38-41]. However, their pharmaceutical development faces big challenge from their low solubility and high toxicity in animal models [29]. Thus, Schluep et al. had made an effort to covalently attach a thiol derivative of TubA to a linear hexacyclodextrin-based polymer via a disulfide linker leading to stable nanoparticles (CDP-TubA) [29]. Upon achieving the nanoparticles, their tubulin polymerization inhibition as well as anti-proliferative activity were tested in vitro. Additionally, in vivo efficacy of CDP-TubA was evaluated by i.v. administration in the nude mice bearing human HT29 colorectal and H460 non-small cell lung carcinoma tumors. CDP-TubA showed minimum inhibition as compared to the bioactive TubA and the active thiol derivative, indicating prerequisite of the release of peptide drug from the nanoparticle for the targeted inhibition. In vivo evaluation of CDP-TubA using a maximum tolerated dose of $6 \mathrm{mg} / \mathrm{Kg}$ showed a potent antitumor effect and significantly prolonged survival compared with TubA alone. These findings suggest that CDP-TubA nanoparticles are highly promising and effective way for the safe delivery of the tubulysin for the treatment of cancer.

\subsubsection{Folate Mediated Delivery of Nanoparticle-Loaded Emtansine}

Maytansine and its analogues, including emtansine (DM1), have been known to be powerful antimitotic agents capable of depolymerizing microtubules by binding to the tubulin receptor at the vinca binding site [42-44]. Maytansine analogues have anti-proliferative activity both in vitro as well as in vivo against a broad spectrum of cancer cell lines including breast cancer, lung carcinoma and murine melanocarcinoma solid tumors [45]. However, therapeutic applications of maytansine and its analogues have been limited by the consequent neurotoxicity and gastrointestinal adverse reactions produced by these analogues [45-47]. In recent years, folate has been broadly accepted as a ligand for the targeted delivery of nanoparticle loaded drugs to the folate receptor positive tumors [45,48-50]. Folate receptors overexpress in a number of tumor cells including ovary, brain, kidney and breast $[45,49,50]$. Lately, it has been demonstrated that folate mediated delivery of drug loaded nanoparticles is capable of enhancing binding, improving uptake and increasing cytotoxicity both in vitro as well as in vivo [51-53]. In this context, recently, Tang et al. synthesized DM1 loaded PLA-TPGS copolymer nanoparticles immobilized with folates (FA-DM1-NPs) [45]. The FA-DM1-NPs turned out to be highly target specific as demonstrated by the uptake of fluorescent nanoparticles by FR $^{+}$MCF-7/HER2 cells. The results also exhibit that FA-DM1-NPs induce rapid apoptosis of tumor cells avoiding toxicities and side effects as well as nonspecific distributions exerted by DM1 alone.

\subsection{3. $\alpha$-Cyclodextrin Mediated Delivery of Curcumin to the Cancer Cell}

Recently, Jana et al. have demonstrated for the first time that $\alpha$-cyclodextrin (CD), a polyhydroxy carbohydrate, interacts with the tubulin receptor at the vinblastine binding site utilizing molecular docking and FRET techniques [54]. They have made use of $\alpha$-cyclodextrin-tubulin interaction to deliver high amount of hydrophobic curcumin to the cancer cell leading to rapid disruption of intracellular microtubules. $\mathrm{CD}$ has been known to accommodate diverse poorly water soluble, hydrophobic drugs in its hydrophobic cavity of different sizes from three different kinds of $\operatorname{CD}(\alpha, \beta, \gamma)$ through formation of inclusion complexes. Thus, CD has been an excellent choice to deliver poorly water soluble drug candidates and currently in use to deliver a number of FDA approved hydrophobic drugs. They have demonstrated that $\alpha$-cyclodextrin-curcumin complex selectively enters human lung cancer cell (A549) as compared to the human normal lung fibroblast (WI38) and delivers tubulin targeting agent curcumin more close to its binding site at the tubulin surface resulting in apoptotic cell death. These findings point that $\mathrm{CD}$ conjugation is highly promising to deliver poorly water soluble hydrophobic tubulin targeting drugs at the tubulin surface. 


\subsection{Nano Particle Delivery of Tubulin Inhibitors Targeting Colchicine Binding Site}

\subsubsection{Nanoparticle Mediated Delivery of Colchicine Alkaloid}

Colchicine was the first known highly potent antimitotic alkaloid and has been widely exploited for the treatment of carcinomas since 1930. Colchicine is known to introduce rapid and severe necrosis and anti-vascular effects in tumors in vivo by depolymerizing microtubule via modulating tubulin receptor $[18,55]$. Colchicine, thus, has been observed to produce anti-angiogenic effects, given that it should be administered over maximum tolerated dose (MTD) [56,57]. However, it is known to pose fatal toxicity to the patients when administered intravenously [56,58,59]. Thus, recently, there has been considerable research on nanoparticle mediated targeted delivery of colchicine to circumvent the toxicity exerted by it. Recently, Tangutoori et al. [56] reported development and in vitro as well as in vivo characterization of PEGylated Cationic Liposomal-colchicine (PCL-colchicine) nanoparticles for the treatment of lung cancer. One of the primary needs for the PEG coated (PEGylation) nanoparticles is to avoid steric or adhesive hindrances caused by cytoskeletal and cellular organelles in the cytoplasm in order to achieve efficient intracellular transport of nanoparticles [60]. Their results demonstrate that microtubules are more efficiently disrupted by nanoparticle-loaded colchicine. Their in vivo experiments indicate two-fold enhanced accumulation of PCL-colchicine in the malignant lung as compared to the normal lung, yielding longer survival time for the PCL-colchicine treated group.

\subsubsection{Delivery of LY293}

Recently, Mundra et al. reported on the formulation of one of the most potent tubulin inhibitors, the 5-indolyl derivative (2-(1H-indol-5-yl) thiazol-4-yl)-3,4,5-trimethoxyphenylmethanone (LY293), into a biodegradable co-polymer, mPEG-b-P (CB-co-LA), in an attempt to determine its anticancer activity and mechanism of action [26,28]. LY293, discovered by Dr. Miller and Li's group, has been found to be highly promising for the treatment of resistant melanoma cell line [61,62]. However, the drug is highly hydrophobic, leading to poor solubility [26,28]. The nanoparticles with loaded drugs have been observed to efficiently reduce the proliferation of A375 and B16F10 melanoma cells in vitro through concentration dependent cell cycle arrest in G2/M phase and apoptotic cell death [26,28]. In continuation, the LY293 loaded nanoparticles showed potent anti-proliferative effect against Pgp overexpressing MDA-MB435/LCC6 MDR1 melanoma cells in vitro and showed the ability to overcome multi drug resistance. Additionally, in vivo experiments with LY293 loaded nanoparticles exhibited strong inhibition of proliferation of highly aggressive metastasized melanoma mouse model without noticeable toxicity to the important organs. In summary, the LY293 loaded nanoparticles demonstrated highly promising efficacy against resistance melanoma cells both in vitro and in vivo. These findings strongly advocate for the nanoparticles as an excellent technique for the safe delivery of various highly potent poorly soluble as well as toxic tubulin inhibitors o the specific target.

\subsubsection{Delivery of Combretastatin A-4}

Combretastatin A-4 (CA4) is an antiangiogenic agent that exert its biological effects by binding to the tubulin receptor at the colchicine binding site. Ten years ago, Sengupta et al. [63] developed PEG-phospholipid copolymer coated PLGA (PEG/PLGA) nanoparticles consisting of a chemo-therapeutic agent doxorubicin (Dox) conjugated to the nanoparticle and an antiangiogenic drug CA4 trapped within the lipid envelope. This staller combination drug delivery system has shown far superior antiproliferative effects than either component of the mixture alone. Their findings suggested that disruption of outer lipid envelope took place inside a tumor leading to rapid deployment of antiangiogenic drug CA4 causing vascular destruction, followed by slow release of the cytotoxic drug Dox from the nanoparticle killing the tumor by increasing apoptotic potential. Recently, Li et al. [64] have come up with a multi-drug delivery system (DDS) based on mesoporous silica nanoparticles (MSNs) exploiting the strategy discovered by Sengupta et al. Li et al. Have demonstrated co-loading of antiangiogenic CA4 and chemotherapeutic Dox in the MSNs followed by anchoring the MSNs 
onto the iRGD peptide that has been reported to be the ligand with high affinity for $\alpha_{2} \beta_{3}$ receptor overexpressed by a number of tumor cells as well as endothelial cells. Results demonstrated that the antiangiogenic CA4 was released from the DDS rapidly and target specifically at the tumor vasculature as soon as the DDS arrives at the tumor vasculature as guided by the iRGD. Later, upon uptake of DDS by the tumor cells, the chemotherapeutic Dox gets released predominantly within the cells of low $\mathrm{pH}$. This mechanism of action led to significantly improved antiangiogenic and anticancer effects in vivo including complete suppression of tumor growth in three weeks at very low Dox dose. Recently, Sanyal et al. [65] reported development of dendron-polymer conjugates (DPDs) capable of conjugating with anti-angiogenic CA4. They have demonstrated that drug release from the DPDs increases as $\mathrm{pH}$ decreases indicating potential improvement in drug release upon internalization in the acidic tumor cells which are low in $\mathrm{pH}$. The DPDs-CA4 construct has shown far superior cytotoxicity than the DPSs alone in the in vitro cellular internalization and toxicity studies. Also, effective antiangiogenic effect of the DPDs-CA4 construct was confirmed by the in vitro endothelial cell tube formation assay.

\subsubsection{Delivery of Etoposide}

Recently, Athawale et al. reported that the solid lipid nanoparticles (SLN) mediated delivery of etoposide, potent tubulin polymerization inhibitor, circumvented the issues associated with its low solubility as well as the low bioavailability [27]. They have evaluated the etoposide loaded SLN for the in vitro dissolution and cytotoxicity assay as well as for in vivo distribution of the dug. In vivo chemotherapeutic activity of the nanoparticle loaded drug was studied by conducting anti-metastatic activity on a B16F10 melanoma mouse model. The results of the MTT assay demonstrated the prepared nanoparticles showed potent in vitro cytotoxicity in concentration and time dependent manner. The in vitro cytotoxicity results were in concert with the in vitro dissolution assay. This article reports significant improvement in the pharmacokinetic parameters of etoposide upon administration as etoposide-SLN (Et-SLN) nanoparticles. In continuation, the bio distribution pattern exhibited higher distribution of the drug in liver and lung as compared to the etoposide alone. The in vivo anti-metastatic study portrayed significant reduction in the metastasized tumor colonies with the administration of the Et-SLN as compared to the etoposide alone. These findings strongly suggest that Et-SLN technology can be further developed for the treatment of highly metastasizing melanoma without having to worry about the low solidity of etoposide.

\subsection{Nano Particle Delivery of Tubulin Inhibitors Targeting Paclitaxel Binding Site}

\section{Delivery of Paclitaxel}

Recently, Houghton et al. reported on the successful evaluation of albumin-bound paclitaxel (nab-pac) against Pediatric Preclinical Testing Program (PPTP) solid tumors [66]. Paclitaxel is an antimitotic natural product that stabilizes tubulin by preventing depolymerization and, thus, promoting disturbance of mitotic cellular functions resulting in cell death [67-69]. Paclitaxel has broad spectrum antiproliferative activity, including ovarian and breast cancer [66]. However, clinical use of paclitaxel is limited by the toxic effect of anti-mitotic agents on the proliferating cells and poor solubility that comes from the hydrophobicity of paclitaxel [66]. Thus, the original formulation of paclitaxel uses polyoxyethy-lated castor oil (Cremophor EL) known to create severe or fatal hypersensitivity reactions [70-74]. Additionally, cremophor is responsible for peripheral neuropathy and limited penetration of paclitaxel [75-77]. The nanoparticle albumin binding drug delivery technology exploits the biochemical properties of albumin to enhance drug delivery to the tumors via albumin introduced transcytosis. The nab-pac, solvent free particle form of paclitaxel, is the first commercial product of this technology [66]. Recently, a Phase 3 clinical trial, that compared the activity and tolerability of nab-pac to that paclitaxel in women with metastatic breast cancer, showed that nab-pac is significantly favored over paclitaxel alone [66,78]. In addition, nab-pac has recently been approved for the treatment of metastatic non-small-cell lung carcinoma in 2012 as well as for metastatic pancreatic cancer 
in 2013 with significant advantage over solvent based PTX formulation [79-81]. Moreover, no severe hypersensitivity reactions occurred in the nab-paclitaxel group, despite the shorter administration time and the absence of premedication. Houghton et al. proved that the activity of nab-paclitaxel against pediatric models of rhabdomyosarcoma and neuroblastoma revealed noticeable in vivo activity superior to that of paclitaxel [66]. In continuation, due to mild and manageable side effects, nab-pac is preferred over PTX in combination with other cytotoxic and targeted agents. Recently, Bansal et al. [82] reported construction of bovine serum albumin (BSA) based nanoparticles mediated delivery of paclitaxel with the ability to controlled release of drug until $24 \mathrm{~h}$. They have also prepared polysorbate 80/Tween 80 (P80) coated BSA-paclitaxel and its blood brain barrier crossing ability was tested in vivo along with the uncoated counterpart as well as the paclitaxel itself. In vivo experiments showed that P80 coated BSA-paclitaxel reached the mouse brain in significantly high concentrations than either the uncoated BSA-paclitaxel or paclitaxel itself. These findings strongly advocate for the nanoparticle ability to cross the blood brain barrier. In the context of brain tumors, lately, Wang et al. [83] have reported development and testing of Pep-1-conjugated PEGylated nanoparticles loaded with paclitaxel (Pep-NP-PTX) as a targeted drug delivery system for the treatment of glioma. They have shown that Pep-NP-PTX system has been uptaken by the glioma cells at significantly higher amount than the NP-PTX system. In vitro cytotoxicity assay has demonstrated two fold higher cytotoxicity of Pep-NP-PTX than NP-PTX system. In continuation, in vivo experiments have suggested that Pep-NP-PTX system has higher distribution in glioma tissues as compared to normal tissues upon administration. Finally, they have found that Pep-NP-PTX system has far superior glioma efficacy resulting in considerable higher survival time (32 days) than either the NP-PTX system (23 days) or he PTX alone (22 days). Recently, Fu and Gong et al. [84] have reported Human Serum Albumin (HAS)-based nanoparticle delivery system for the co-delivery of pirarubicin (THP) and paclitaxel (PTX) for the treatment of breast cancer aiming at reduced toxicities and enhanced therapeutic efficacies. The prepared co-delivery system has demonstrated high loading capacity and sustained release ability. In vivo experiments with 4T1 murine breast cancer cell lines have exhibited significantly higher drug concentrations in tumor cells and lower drug distribution in normal tissues. In vitro cytotoxicity assay as well as in vivo antitumor assays have exhibited far superior antitumor effect of the THP and PTX loaded co-delivery system than either single drug or free combination. Additionally, PTX and THP loaded co-delivery system have demonstrated the ability to induce rapid apoptosis in $4 \mathrm{~T} 1$ breast cancer cell lines as well as considerably lower side effects. Table 1 summarizes the recent advances in nanoparticle mediated delivery of tubulin inhibitors and the advantages of nanoparticle-drug conjugates as compared to the free drug alone as discussed above. 
Table 1. Nanoparticle mediated delivery of tubulin inhibitors.

\begin{tabular}{|c|c|c|c|c|}
\hline Drugs & Formulation & Active/Passive & Advantage & References \\
\hline Tubulysine A & $\begin{array}{l}\text { Thiol derivative of TubA attached to a linear } \\
\text { hexacyclodextrin based polymer via a disulfide } \\
\text { linker leading to stable nanoparticles (CDP-TubA) }\end{array}$ & Active & $\begin{array}{l}\text { In vivo CDP-TubA showed a potent antitumor effect and significantly prolonged } \\
\text { survival compared with TubA alone }\end{array}$ & Schluep et al. [29] \\
\hline $\begin{array}{l}\text { Emtansine } \\
\text { (DM1) }\end{array}$ & $\begin{array}{l}\text { DM1 loaded PLA-TPGS copolymer nanoparticles } \\
\text { immobilized with folates (FA-DM1-NPs) }\end{array}$ & Active & $\begin{array}{l}\text { FA-DM1-NPs induce rapid apoptosis avoiding toxicities, side effects and } \\
\text { nonspecific distributions exerted by DM1 alone }\end{array}$ & Tang et al. [46] \\
\hline curcumin & $\alpha$-Cyclodextrin & Active & $\begin{array}{l}\alpha \text {-cyclodextrin-curcumin complex selectively enters human lung cancer cell } \\
\text { (A549) as compared to the human normal lung fibroblast (WI38) and delivers } \\
\text { hydrophobic curcumin }\end{array}$ & Jana et al. [55] \\
\hline $\begin{array}{l}\text { Colchicine } \\
\text { alkaloid }\end{array}$ & $\begin{array}{l}\text { PEGylated Cationic Liposomal-colchicine } \\
\text { (PCL-colchicine) nanoparticles }\end{array}$ & Passive & $\begin{array}{l}\text { Microtubules are more efficiently disrupted by nanoparticle-loaded colchicine. } \\
\text { In vivo longer survival time for the PCL-colchicine treated group }\end{array}$ & Tangutoori et al. [56] \\
\hline LY293 & Biodegradable co-polymer, mPEG-b-P (CB-co-LA) & Passive & $\begin{array}{l}\text { LY293 loaded nanoparticles demonstrated highly promising efficacy against } \\
\text { resistance melanoma cells both in vitro and in vivo without noticeable toxicities to } \\
\text { the important organs }\end{array}$ & Mundra et al. $[26,28]$ \\
\hline $\begin{array}{l}\text { Combretastatin } \\
\text { A-4 (CA4) }\end{array}$ & $\begin{array}{l}\text { Multi drug delivery system (DDS) based on } \\
\text { mesoporous silica nanoparticles (MSNs) followed } \\
\text { by anchoring the MSNs onto the iRGD peptide }\end{array}$ & Active & $\begin{array}{l}\text { 1. Co-loading of antiangiogenic CA4 and chemotherapeutic Dox in the MSNs. } \\
\text { 2. CA4 is released from the DDS rapidly and target specifically at the tumor } \\
\text { vasculature. Later the Dox gets released predominantly within the cells of low } \mathrm{pH}\end{array}$ & Li et al. [64] \\
\hline $\begin{array}{l}\text { Combretastatin } \\
\text { A-4 (CA4) }\end{array}$ & Dendron-polymer conjugates (DPDs) & Passive & $\begin{array}{l}\text { The DPDs-CA4 construct has shown far superior cytotoxicity than the DPSs alone } \\
\text { in the in vitro cellular internalization and toxicity studies }\end{array}$ & Sanyal et al. [65] \\
\hline Etoposide & Solid lipid nanoparticles (SLN) & Passive & $\begin{array}{l}\text { Circumvented the issues associated with its low solubility as well as the low } \\
\text { bioavailability. in vivo significant reduction in the metastasized tumor colonies as } \\
\text { compared to the etoposide alone }\end{array}$ & Athawale et al. [27] \\
\hline Paclitaxel & Albumin-bound paclitaxel (nab-pac) & Active & $\begin{array}{l}\text { Activity of nab-paclitaxel against pediatric models of rhabdomyosarcoma and } \\
\text { neuroblastoma revealed noticeable in vivo activity superior to that of paclitaxel }\end{array}$ & Houghton et al. [67] \\
\hline Paclitaxel & $\begin{array}{l}\text { polysorbate } 80 / \text { Tween } 80 \text { (P80) coated } \\
\text { BSA-paclitaxel }\end{array}$ & Passive & $\begin{array}{l}\text { In vivo experiments exhibited that P80 coated BSA-paclitaxel reached the mouse } \\
\text { brain in significantly high concentrations than either the uncoated BSA-paclitaxel } \\
\text { or paclitaxel itself }\end{array}$ & Bansal et al. [82] \\
\hline Paclitaxel & $\begin{array}{l}\text { Pep-1-conjugated PEGylated nanoparticles } \\
\text { (Pep-NP-PTX) }\end{array}$ & Active & $\begin{array}{l}\text { Pep-NP-PTX system has been uptaken by the glioma cells at significantly higher } \\
\text { amount than the NP-PTX system }\end{array}$ & Wang et al. [83] \\
\hline
\end{tabular}




\section{Vascular Disrupting Agents and Antiangiogenic Agents}

In recent years there has been considerable interest in vascularization for the metastasis and growth of malignant tumors $[19,55]$. It is scientifically accepted that a solid tumor cannot grow without the blood vessels providing access to the nutrients and oxygen necessary for the tumor survival [55]. Currently, there are two different ways to target tumor vascularization, namely: (a) inhibition of angiogenesis or formation of new blood vessels; and (b) disruption of already existing blood vessels [55,85-87]. In recent years, angiogenesis has been extensively studied revealing the cause underlying this process under physiological and pathological conditions [88]. The recent angiogenesis research has provided access to a number of FDA approved drugs, including small molecules and monoclonal antibodies, inhibiting angiogenesis [89]. However, antiangiogenic drugs could not keep up with the expectations as clinical data revealed that treatment with antiangiogenic agents suffer from resistance development, lack of efficacy, as well as toxicity [90]. The second approach, disruption of already existing blood vessels, counts on Vascular Disrupting Agents (VDAs). VDAs are known to promote rapid collapse of tumor vasculature resulting in necrosis at the tumor [19]. The research has proven that antiangiogenic compounds are especially useful at early stage tumors, small tumors, requiring prolong and chronical administration [55]. On the contrary, VDAs are highly cytotoxic and employs its rapid effect on the existing tumor vessels resulting in quick vascular collapse and ultimate tumor cell death [15]. Thus, VDAs are useful against large tumors and require acute administration [15]. Additionally, the VDAs may be more effective for the aggressive tumors that are resistant to chemotherapy and radiotherapy, given VDAs target tumor vasculature. In this review we will be discussing the recent development of VDAs as well as antiangiogenic agents that are tubulin destabilizing agents capable of inducing vascular collapse through rapid depolymerization of microtubules. In recent years, there has been extensive research on the design and development of VDAs as well as antiangiogenic agents that act at the colchicine binding cite $[19,23,91,92]$. Here, we will primarily be focusing on recent advances on two different classes, namely (1) combretastatin A-4 (CA-4) and its derivatives and (2) non-CA-4 analogues. It is noteworthy that both of the classes belong to the MDA family. There are a number of reports on the antiangiogenic properties of MSAs including paclitaxel, peloruside A as well as laulimalide [93-98]. However, antiangiogenic applications of MSAs has faced a number of limitations including (a) resistance to MSAs and (b) neurological as well as bone marrow toxicity [8,94]. In MSA family, paclitaxel (MSA) has been extensively studied, in recent years, for its promising antiangiogenic activity both as a free drug as well as loaded in the nanoparticles [96,98]. However, VDAs and antiangiogenic agents from MDA family had become increasingly popular in recent years in both academic and industrial arena. Thus, here, we will be focusing on the two different classes of VDAs and antiangiogenic agents that belong to the MDA family of tubulin inhibitors.

\subsection{VDAs and Antiangiogenic Agents from the CA-4 Family}

Combretastatins are a family of naturally occurring stilbenoid phenols and derivatives (Figure 3). They are a well-studied class of small molecule VDAs and antiangiogenic agents with the ability to exert their microtubule destabilizing effects by binding to the colchicine binding site at the $\beta$-subunit of tubulin $[99,100]$. CA-4 class agents are highly cytotoxic against broad spectrum of human tumor cell lines including the ones that are multi drug resistant (MDR) $[19,101]$. Promising potential as anti-cancer agents and simple structure of this family have brought them to the attention of medicinal chemists. Thus, in recent years, CA-4 family has undergone extensive structural alterations leading to very promising VDAs and antiangiogenic agents including the ones currently in clinical trials $[19,92]$. In this section we will focus on recently developed, from years 2010 to 2016, VDAs and antiangiogenic agents belonging to CA-4 class of tubulin depolymerizing agents. 
<smiles>COc1ccc(-c2ccc(OC)c(OC)c2)cc1OC</smiles><smiles>COc1cc2c(c(OC)c1OC)-c1ccc(OP(=O)(O)O)cc1C(NC(C)=O)CC2</smiles>

Combretastatin A-4 (CA-4)

ZD6126<smiles>COc1cc(C(=O)c2c(C)oc3c(OC)ccc(OC)c23)cc(OC)c1OC</smiles>

BNC105P

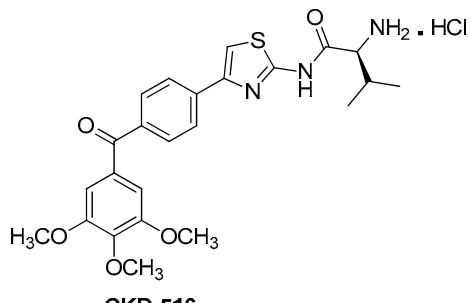

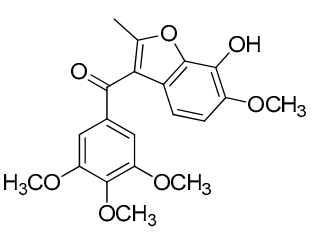

BNC105

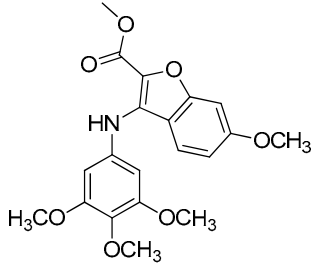

Romagnoli 2015

Figure 3. Recently developed VDAs and antiangiogenic agents from the CA-4 family.

\subsubsection{ZD6126}

Amongst the CA-4 family, the compound that has been extended for further development is the phosphate prodrug ZD6126 [19,55]. ZD6126 is known as a water soluble prodrug of the tubulin polymerization inhibitor $\mathrm{N}$-acetylcolchinol (NAC). In vivo, ZD6126, is rapidly hydrolyzed to its active metabolite, NAC, that occludes tumor blood vessels resulting in shutdown of tumor blood flow and, thus, induces tumor cell death $[19,101]$. ZD6126 is highly effective in shutting down newly formed blood vessels right after injection. In experimental tumor models, ZD6126 has been found to induce rapid blood vessel shut down and significant tumor necrosis at doses of 25-50 mg/ $\mathrm{kg}[19,102,103]$. In a phase 1 clinical trial a ZD6126 dose of up to $80 \mathrm{mg} / \mathrm{m}^{2}$ was well tolerated [19]. This compound exhibited higher vascular disrupting effects than antimitotic activity [19]. However, its clinical development has been put on hold due to severe cardiotoxicity [55].

\subsubsection{CKD 516}

CKD 516 was obtained as a potent tubulin polymerization inhibitor through structural modification of CA-4 [104,105]. It is highly cytotoxic against a number of malignant cell lines including the MDR positive cell lines [19]. It exhibits significant vascular disruption leading to rapid tumor necrosis at a dose of $0.7 \mathrm{mg} / \mathrm{kg}[19,106]$. Thus, it is a highly potent VDA capable of exerting its effect through tubulin component of the tumor vessel. A recent phase 1 clinical trial of CKD 516 demonstrated that it is safe and well tolerated in the patients with advanced solid tumors at the maximum tolerated dose (MTD) of $12 \mathrm{mg} / \mathrm{m}^{2}$, administered on D1 and D8 every three weeks [107].

\subsubsection{BNC 105 and BNC 105P}

BNC causes damage to existing tumor vessels by binding to the colchicine binding site of tubulin [108]. BNC 105 demonstrates 80-fold more selectivity against proliferating endothelial cells as compared to CA-4 that does not show any selectivity [19]. BNC 105 has been found to cause $95 \%$ vascular disruption at $1 / 8$ th of its no observed adverse event level (NOAEL) and, thus, has emerged as a potent disruptor of tumor vasculature [19]. It is currently undergoing a phase I clinical trial.

BNC 105P is a disodium phosphate prodrug of BNC 105 that exhibits the capability of disrupting the vasculature of solid tumors in mice [109]. In vivo, at a dose of $10 \mathrm{mg} / \mathrm{kg}$ BNC 105P exerts greater vessel disruption (>95\%) than BNC 105 alone [109]. Currently, it is undergoing a phase I clinical trial. 


\subsubsection{Benzofuran CA-4 Derivative}

Recently, Ramognoli et al. reported the discovery of a highly potent benzofuran microtubule destabilizing agent capable of exerting its tubulin depolymerization effect by binding to the colchicine binding site of the tubulin [91]. It demonstrated strong vascular disrupting properties both in vitro and in vivo as well as potent antitumor activity in vivo in a murine model at a dose of $30 \mathrm{mg} / \mathrm{kg}$.

\subsubsection{TR644}

TR644 is an analogue of CA-4 family with superior microtubule destabilizing effect compared to the lead compound. It exerts it tubulin depolymerization effects by binding to the colchicine binding site of tubulin [92]. It was tested in human umbilical endothelial cells (HUVEC) for antiangiogenic effects and it showed promising inhibitory effect against capillary tube formation as well as endothelial cell migration at a single dose of $30 \mathrm{mg} / \mathrm{kg}$ after $24 \mathrm{~h}$ of treatment. TR644 was found to exert its anti-vascular activity through G2/M phase arrest in endothelial cells.

\subsection{Miscellaneous Recent VDAs and Antiangiogenic Agents}

\subsubsection{Plinabulin (NPI-2358)}

Recently, Yakushiji et al. designed and developed a synthetic derivative of the amrine product diketopiperazine, named pinabulin (NPI-2358, Figure 4) [110]. NPI-2358 is a potent microtubule destabilizing agent that exerts its effect by binding to the colchicine binding site of tubulin. NPI-2358 projects its potent antitumor activity against a broad spectrum of tumor cell lines including DU145, NCI-H292, MDA-MB-231, and PC-3 [19]. NPI-2358 has also been found to demonstrate potent antitumor activity in animal models treated by it. A phase-I study demonstrated its promising vascular disrupting effects by inducing strong microtubule destabilization, at doses from $13.5 \mathrm{mg} / \mathrm{m}^{2}$ to $30 \mathrm{mg} / \mathrm{m}^{2}$ in combination with $75 \mathrm{mg} / \mathrm{m}^{2}$ docetaxel [111]. It is currently undergoing a phase-II clinical trial with docetaxel.<smiles>CC(C)(C)c1[nH]cnc1/C=c1\[nH]c(=O)/c(=C/c2ccccc2)[nH]c1=O</smiles>

Plinabulin (NPI-2358)<smiles>Cc1nc(N(C)c2ccc3c(ccn3C)c2)c2ccccc2n1</smiles>

Azixa Derivative-1<smiles>CCC[C@H](Nc1ccnc(-c2ccc(NC(=O)NCC)c(OC)c2)n1)c1cccnc1</smiles>

CYT-997<smiles>COc1ccc(N(C)c2nc(C)nc3c(Cc4ccccc4)c[nH]c23)cc1</smiles>

Azixa deivative-2<smiles>COc1ccc(N(C)c2nc(C)nc3ccccc23)cc1</smiles>

MPC-6827 (Azixa)<smiles>COc1cc(C2C(C#N)=C(N)Oc3c2ccc(N)c3N)cc(Br)c1OC</smiles>

EPC2407

Figure 4. Examples of recently developed non CA-4 VDAs.

\subsubsection{CYT-997}

Recently Burns et al. designed and synthesized CYT-997 (Figure 4), a highly cytotoxic pyrimidine derivative that works against a range of cancer cell lines through microtubule destabilization [112]. It is also equally effective in a broad spectrum of in vivo tumor models. CYT-997 exhibits strong potential as a VDA inducing rapid and significant morphological changes in human endothelial cells as well 
as shutdown of blood flow to the tumors at concentrations $65 \mathrm{mg} / \mathrm{m}^{2}$ and above $[19,113]$. It also promotes extensive ablation of the tumor vasculature preventing the tumor from enlarging. It is seen to significantly extend survival in vivo in a murine model with aggressive myelomatosis [114].

\subsubsection{Azixa and Its Derivatives}

The 4-arylaminoquinazoline Azixa (MPC-6827 or verbulin, Figure 4), emerged a few years ago as a highly potent tubulin depolymerizing agent capable of inducing cell cycle arrest and cell death achieved via microtubule destabilization [115]. It also found to act as a VDA inducing rapid shutdown of tumor blood flow resulting in inhibition of tumor growth. It works at a low nanomolar range against a variety of tumor cell lines, including brain cancer, melanoma, small cell lung cancer, prostate cancer, and pancreatic cancer [116-118]. Recently, it is reported that MPC-6827 induces rapid tumor vessel occlusion and massive tumor necrosis in the OVCAR-3 xenograft models [19]. It is noteworthy to mention that MPC-6827 has been found to easily penetrate blood brain barrier and quickly distribute to the central nervous system [14]. This success makes it an outstanding candidate against brain metastasis and CNS malignancies with negligible CNS toxicities. The indole derivative of MPC-6827, Azixa derivative-1 (Figure 4) shows highly potent activity against a number of malignant cell lines with $\mathrm{IC}_{50}$ values in the single digit nanomolar range [118]. This compound has been noticed to induce suppression of vessel-like tube formation in endothelial cells as well as destruction of existing blood vessels both in vitro and in vivo at the concentration of $5 \mathrm{mg} / \mathrm{kg}$, resulting in rapid necrosis of tumor cells [19]. Recently, Gangjee et al. reported the design, synthesis and evaluation of another Azixa analogue (Azixa derivative-2, Figure 4) exhibiting both cytotoxic and antiangiogenic activity [23]. The compound produces its cytotoxic activity through microtubule destabilization by binding to the colchicine site of tubulin. The same compound exerts antiangiogenic activity in vivo through VEGFR2 inhibition at a dose of $30 \mathrm{mg} / \mathrm{kg}$ or above. This compound induced rapid reduction in vascularity and tumor size in two flank xenograft model (the BLBC MDA-MB-435 and U251 glioma models) and in a 4T1 triple negative breast orthotopic allograft model.

\subsubsection{EPC2407}

Recently, EpiCept developed EPC2407 (Figure 4) a 4H-chromene analogue that exerts breast cancer apoptosis and cell cycle arrest in G2/M phase by binding to the colchicine binding site of tubulin $[19,119]$. EPC2407 is noticed to disrupt the capillary tube formation in endothelial cell in vitro as well as destroy functional vasculature in vivo at a single dose of $10 \mathrm{mg} / \mathrm{kg}$, inducing rapid necrosis [19]. It is currently undergoing a phase-II clinical trial. Baed on this success, our group also recently reported a number of $4 H$-chromene and chromenopyridine analogues with potential antiangiogenic or VDA activity $[24,119,120]$.

\section{Conclusions and Future Directions}

Recent research in nanoparticle drug delivery of tubulin inhibitors has proven to introduce positive changes in the pharmacokinetics as well as pharmacodynamics of the chemotherapeutics through: (a) improving solubility; (b) enhancing half-life by avoiding first pass kidney clearance; (c) greatly augmenting drug concentrations in tumor cells by improved permeability and retention effects; (d) protecting the drug from enzymatic degradation, as well as (e) circumventing toxicity. Currently, further research has been carried out to overcome the limitations of drug load capacity. In the context of VDAs and antiangiogenic agents, tubulin inhibitors targeting the colchicine binding site have become increasingly popular. Considerable progress has been made in both industrial and academic arenas with more than ten compounds entering in clinical trials as VDAs. One of the biggest advantages of these VDAs over other commonly used chemotherapeutics is their ability to bind reversibly to the colchicine binding pocket and, thus, their reduced toxicity. However, there are still some efficacy and toxicity limitations. Thus, current medicinal chemistry alterations are being carried out focusing on reduction of toxicities and improvement of efficacies related to VDAs. 
Acknowledgments: This work is supported by NIH/NCI grants R01CA148706-06 to Wei Li and Duane D. Miller. Its contents are solely the responsibility of the authors and do not necessarily represent the official views of the NIH/NCI.

Conflicts of Interest: The authors declare no conflict of interest.

\section{References}

1. Borisy, G.G.; Taylor, E.W. The mechanism of action of colchicine. Binding of colchincine- ${ }^{3} \mathrm{H}$ to cellular protein. J. Cell Biol. 1967, 34, 525-533. [CrossRef] [PubMed]

2. Bunker, J.M.; Wilson, L.; Jordan, M.A.; Feinstein, S.C. Modulation of microtubule dynamics by tau in living cells: Implications for development and neurodegeneration. Mol. Biol. Cell 2004, 15, 2720-2728. [CrossRef] [PubMed]

3. Risinger, A.L.; Dybdal-Hargreaves, N.F.; Mooberry, S.L. Breast cancer cell lines exhibit differential sensitivities to microtubule-targeting drugs independent of doubling time. Anticancer Res. 2015, 35, 5845-5850. [PubMed]

4. Perez-Elias, M.J.; Morellon, M.L.; Ortega, E.; Hernandez-Quero, J.; Rodriguez-Torres, M.; Clotet, B.; Felizarta, F.; Gutierrez, F.; Pineda, J.A.; Nichols, G.; et al. Pharmacokinetics of fosamprenavir plus ritonavir in human immunodeficiency virus type 1-infected adult subjects with hepatic impairment. Antimicrob. Agents Chemother. 2009, 53, 5185-5196. [CrossRef] [PubMed]

5. Gan, P.P.; McCarroll, J.A.; Po'uha, S.T.; Kamath, K.; Jordan, M.A.; Kavallaris, M. Microtubule dynamics, mitotic arrest, and apoptosis: Drug-induced differential effects of $\beta I I I-t u b u l i n$. Mol. Cancer Ther. 2010, 9 , 1339-1348. [CrossRef] [PubMed]

6. Brouhard, G.J.; Rice, L.M. The contribution of $\alpha \beta$-tubulin curvature to microtubule dynamics. J. Cell Biol. 2014, 207, 323-334. [CrossRef] [PubMed]

7. Zhao, Y.; $\mathrm{Mu}, \mathrm{X} . ; \mathrm{Du}, \mathrm{G}$. Microtubule-stabilizing agents: New drug discovery and cancer therapy. Pharmacol. Ther. 2016, 162, 134-143. [CrossRef] [PubMed]

8. Fanale, D.; Bronte, G.; Passiglia, F.; Calo, V.; Castiglia, M.; Di Piazza, F.; Barraco, N.; Cangemi, A.; Catarella, M.T.; Insalaco, L.; et al. Stabilizing versus destabilizing the microtubules: A double-edge sword for an effective cancer treatment option? Anal. Cell. Pathol. 2015, 2015, 690916. [CrossRef] [PubMed]

9. Morris, P.G.; Fornier, M.N. Microtubule active agents: Beyond the taxane frontier. Clin. Cancer Res. 2008, 14, 7167-7172. [CrossRef] [PubMed]

10. Hwang, D.J.; Wang, J.; Li, W.; Miller, D.D. Structural optimization of indole derivatives acting at colchicine binding site as potential anticancer agents. ACS Med. Chem. Lett. 2015, 6, 993-997. [CrossRef] [PubMed]

11. Prota, A.E.; Bargsten, K.; Northcote, P.T.; Marsh, M.; Altmann, K.H.; Miller, J.H.; Diaz, J.F.; Steinmetz, M.O. Structural basis of microtubule stabilization by laulimalide and peloruside A. Angew. Chem. Int. Ed. Engl. 2014, 53, 1621-1625. [CrossRef] [PubMed]

12. Perez, E.A. Microtubule inhibitors: Differentiating tubulin-inhibiting agents based on mechanisms of action, clinical activity, and resistance. Mol. Cancer Ther. 2009, 8, 2086-2095. [CrossRef] [PubMed]

13. Ravelli, R.B.; Gigant, B.; Curmi, P.A.; Jourdain, I.; Lachkar, S.; Sobel, A.; Knossow, M. Insight into tubulin regulation from a complex with colchicine and a stathmin-like domain. Nature 2004, 428, 198-202. [CrossRef] [PubMed]

14. Spear, M.A.; LoRusso, P.; Mita, A.; Mita, M. Vascular disrupting agents (VDA) in oncology: Advancing towards new therapeutic paradigms in the clinic. Curr. Drug Targets 2011, 12, 2009-2015. [CrossRef] [PubMed]

15. Siemann, D.W. The unique characteristics of tumor vasculature and preclinical evidence for its selective disruption by tumor-vascular disrupting agents. Cancer Treat. Rev. 2011, 37, 63-74. [CrossRef] [PubMed]

16. Prokopiou, E.M.; Ryder, S.A.; Walsh, J.J. Tumour vasculature targeting agents in hybrid/conjugate drugs. Angiogenesis 2013, 16, 503-524. [CrossRef] [PubMed]

17. Lobert, S.G.; Mary, E. Regulation of tubulin expression by micro-RNA: Implications drug resistance. Methods Cell Biol. 2013, 115, 63-74. [PubMed]

18. Lu, Y.; Chen, J.; Xiao, M.; Li, W.; Miller, D.D. An overview of tubulin inhibitors that interact with the colchicine binding site. Pharm. Res. 2012, 29, 2943-2971. [CrossRef] [PubMed]

19. Ji, Y.T.; Liu, Y.N.; Liu, Z.P. Tubulin colchicine binding site inhibitors as vascular disrupting agents in clinical developments. Curr. Med. Chem. 2015, 22, 1348-1360. [CrossRef] [PubMed] 
20. Wang, X.-F.; Guan, F.; Ohkoshi, E.; Guo, W.; Wang, L.; Zhu, D.-Q.; Wang, S.-B.; Wang, L.-T.; Hamel, E.; Yang, D.; et al. Optimization of 4-(N-cycloamino)phenylquinazolines as a novel class of tubulin-polymerization inhibitors targeting the colchicine site. J. Med. Chem. 2014, 57, 1390-1402. [CrossRef] [PubMed]

21. Solum, E.J.; Cheng, J.-J.; Sørvik, I.B.; Paulsen, R.E.; Vik, A.; Hansen, T.V. Synthesis and biological evaluations of new analogs of 2-methoxyestradiol: Inhibitors of tubulin and angiogenesis. Eur. J. Med. Chem. 2014, 85, 391-398. [CrossRef] [PubMed]

22. O'Boyle, N.M.; Pollock, J.K.; Carr, M.; Knox, A.J.S.; Nathwani, S.M.; Wang, S.; Caboni, L.; Zisterer, D.M.; Meegan, M.J. B-lactam estrogen receptor antagonists and a dual-targeting estrogen receptor/tubulin ligand. J. Med. Chem. 2014, 57, 9370-9382. [CrossRef] [PubMed]

23. Gangjee, A.; Pavana, R.K.; Ihnat, M.A.; Thorpe, J.E.; Disch, B.C.; Bastian, A.; Bailey-Downs, L.C.; Hamel, E.; Bai, R. Discovery of antitubulin agents with antiangiogenic activity as single entities with multitarget chemotherapy potential. ACS Med. Chem. Lett. 2014, 5, 480-484. [CrossRef] [PubMed]

24. Patil, S.A.; Wang, J.; Li, X.S.; Chen, J.; Jones, T.S.; Hosni-Ahmed, A.; Patil, R.; Seibel, W.L.; Li, W.; Miller, D.D. New substituted $4 \mathrm{H}$-chromenes as anticancer agents. Bioorg. Med. Chem. Lett. 2012, 22, 4458-4461. [CrossRef] [PubMed]

25. Chen, W.; Seefeldt, T.; Young, A.; Zhang, X.; Zhao, Y.; Ruffolo, J.; Kaushik, R.S.; Guan, X. Microtubule $S$-glutathionylation as a potential approach for antimitotic agents. BMC Cancer 2012, 12. [CrossRef] [PubMed]

26. Mundra, V.; Peng, Y.; Kumar, V.; Li, W.; Miller, D.D.; Mahato, R.I. Systemic delivery of nanoparticle formulation of novel tubulin inhibitor for treating metastatic melanoma. Drug Deliv. Transl. Res. 2015, 5, 199-208. [CrossRef] [PubMed]

27. Athawale, R.B.; Jain, D.S.; Singh, K.K.; Gude, R.P. Etoposide loaded solid lipid nanoparticles for curtailing B16F10 melanoma colonization in lung. Biomed. Pharmacother. 2014, 68, 231-240. [CrossRef] [PubMed]

28. Mundra, V.; Lu, Y.; Danquah, M.; Li, W.; Miller, D.D.; Mahato, R.I. Formulation and characterization of polyester/polycarbonate nanoparticles for delivery of a novel microtubule destabilizing agent. Pharm. Res. 2012, 29, 3064-3074. [CrossRef] [PubMed]

29. Schluep, T.; Gunawan, P.; Ma, L.; Jensen, G.S.; Duringer, J.; Hinton, S.; Richter, W.; Hwang, J. Polymeric tubulysin-peptide nanoparticles with potent antitumor activity. Clin. Cancer Res. 2009, 15, 181-189. [CrossRef] [PubMed]

30. Reddy, J.A.; Dorton, R.; Westrick, E.; Dawson, A.; Smith, T.; Xu, L.-C.; Vetzel, M.; Kleindl, P.; Vlahov, I.R.; Leamon, C.P. Preclinical evaluation of EC145, a folate-vinca alkaloid conjugate. Cancer Res. 2007, 67, 4434-4442. [CrossRef] [PubMed]

31. Carter, P.J.; Senter, P.D. Antibody-drug conjugates for cancer therapy. Cancer J. 2008, 14, 154-169. [CrossRef] [PubMed]

32. Thomas, A.; Teicher, B.A.; Hassan, R. Antibody-drug conjugates for cancer therapy. Lancet Oncol. 2016, 17, e254-e262. [CrossRef]

33. Polakis, P. Antibody drug conjugates for cancer therapy. Pharmacol. Rev. 2016, 68, 3-19. [CrossRef] [PubMed]

34. Vicent, M.J. Polymer-drug conjugates as modulators of cellular apoptosis. AAPS J. 2007, 9, E200-E207. [CrossRef] [PubMed]

35. Kaur, G.; Hollingshead, M.; Holbeck, S.; Schauer-Vukašinović, V.; Camalier, R.F.; Dömling, A.; Agarwal, S. Biological evaluation of tubulysin A: A potential anticancer and antiangiogenic natural product. Biochem. J. 2006, 396, 235-242. [CrossRef] [PubMed]

36. Steinmetz, H.; Glaser, N.; Herdtweck, E.; Sasse, F.; Reichenbach, H.; Höfle, G. Isolation, crystal and solution structure determination, and biosynthesis of tubulysins-Powerful inhibitors of tubulin polymerization from myxobacteria. Angew. Chem. Int. Ed. Engl. 2004, 43, 4888-4892. [CrossRef] [PubMed]

37. Khalil, M.W.; Sasse, F.; Lünsdorf, H.; Elnakady, Y.A.; Reichenbach, H. Mechanism of action of tubulysin, an antimitotic peptide from myxobacteria. ChemBioChem 2006, 7, 678-683. [CrossRef] [PubMed]

38. Murray, B.C.; Peterson, M.T.; Fecik, R.A. Chemistry and biology of tubulysins: Antimitotic tetrapeptides with activity against drug resistant cancers. Nat. Prod. Rep. 2015, 32, 654-662. [CrossRef] [PubMed]

39. Nicolaou, K.C.; Yin, J.; Mandal, D.; Erande, R.D.; Klahn, P.; Jin, M.; Aujay, M.; Sandoval, J.; Gavrilyuk, J.; Vourloumis, D. Total synthesis and biological evaluation of natural and designed tubulysins. J. Am. Chem. Soc. 2016, 138, 1698-1708. [CrossRef] [PubMed] 
40. Colombo, R.; Wang, Z.; Han, J.; Balachandran, R.; Daghestani, H.N.; Camarco, D.P.; Vogt, A.; Day, B.W.; Mendel, D.; Wipf, P. Total synthesis and biological evaluation of tubulysin analogues. J. Org. Chem. 2016. [CrossRef] [PubMed]

41. Xu, X.; Gregory, K.F.; Yao, L. Recent advances in the synthesis of tubulysins. Mini Rev. Med. Chem. 2013, 13, 1572-1578.

42. Sendur, M.A.; Aksoy, S.; Ozdemir, Y.; Zengin, N.; Altundag, K. Does trastuzumab-emtansine have better cardiac safety profile in contrast to trastuzumab? J. BUON 2013, 18, 801. [PubMed]

43. Bighin, C.; Pronzato, P.; Del Mastro, L. Trastuzumab emtansine in the treatment of HER-2-positive metastatic breast cancer patients. Future Oncol. 2013, 9, 955-957. [CrossRef] [PubMed]

44. Poon, K.A.; Flagella, K.; Beyer, J.; Tibbitts, J.; Kaur, S.; Saad, O.; Yi, J.H.; Girish, S.; Dybdal, N.; Reynolds, T. Preclinical safety profile of trastuzumab emtansine (T-DM1): Mechanism of action of its cytotoxic component retained with improved tolerability. Toxicol. Appl. Pharmacol. 2013, 273, 298-313. [CrossRef] [PubMed]

45. Tang, X.; Liang, Y.; Zhu, Y.; Cai, S.; Sun, L.; Chen, T. Enhanced anticancer activity of DM1-loaded star-shaped folate-core PLA-TPGS nanoparticles. Nanoscale Res. Lett. 2014, 9. [CrossRef] [PubMed]

46. Haddley, K. Trastuzumab emtansine for the treatment of HER2-positive metastatic breast cancer. Drugs Today 2013, 49, 701-715. [CrossRef] [PubMed]

47. Thery, J.-C.; Spano, J.-P.; Azria, D.; Raymond, E.; Penault Llorca, F. Resistance to human epidermal growth factor receptor type 2-targeted therapies. Eur. J. Cancer 2014, 50, 892-901. [CrossRef] [PubMed]

48. Ye, P.; Zhang, W.; Yang, T.; Lu, Y.; Lu, M.; Gai, Y.; Ma, X.; Xiang, G. Folate receptor-targeted liposomes enhanced the antitumor potency of imatinib through the combination of active targeting and molecular targeting. Int. J. Nanomed. 2014, 9, 2167-2178. [CrossRef] [PubMed]

49. Hu, Y.; Ma, B.; Zhang, Y.; Wang, M. Small molecule-folic acid modification on nanopatterned PDMS and investigation on its surface property. Biomed. Microdevices 2014, 16, 487-497. [CrossRef] [PubMed]

50. Leamon, C.P.; Vlahov, I.R.; Reddy, J.A.; Vetzel, M.; Santhapuram, H.K.; You, F.; Bloomfield, A.; Dorton, R.; Nelson, M.; Kleindl, P.; et al. Folate-vinca alkaloid conjugates for cancer therapy: A structure-activity relationship. Bioconjug. Chem. 2014, 25, 560-568. [CrossRef] [PubMed]

51. Shi, J.; Wang, L.; Gao, J.; Liu, Y.; Zhang, J.; Ma, R.; Liu, R.; Zhang, Z. A fullerene-based multi-functional nanoplatform for cancer theranostic applications. Biomaterials 2014, 35, 5771-5784. [CrossRef] [PubMed]

52. Zheng, M.; Zhao, P.; Luo, Z.; Gong, P.; Zheng, C.; Zhang, P.; Yue, C.; Gao, D.; Ma, Y.; Cai, L. Robust ICG theranostic nanoparticles for folate targeted cancer imaging and highly effective photothermal therapy. ACS Appl. Mater. Interfaces 2014, 6, 6709-6716. [CrossRef] [PubMed]

53. Torchilin, V. Tumor delivery of macromolecular drugs based on the EPR effect. Adv. Drug Deliv. Rev. 2011, 63, 131-135. [CrossRef] [PubMed]

54. Jana, B.; Mohapatra, S.; Mondal, P.; Barman, S.; Pradhan, K.; Saha, A.; Ghosh, S. A-cyclodextrin interacts close to vinblastine site of tubulin and delivers curcumin preferentially to the tubulin surface of cancer cell. ACS Appl. Mater. Interfaces 2016, 8, 13793-13803. [CrossRef] [PubMed]

55. Pérez-Pérez, M.-J.; Priego, E.-M.; Bueno, O.; Martins, M.S.; Canela, M.-D.; Liekens, S. Blocking blood flow to solid tumors by destabilizing tubulin: An approach to targeting tumor growth. J. Med. Chem. 2016, 59, 8685-8711. [CrossRef] [PubMed]

56. Tangutoori, S.; Ohta, A.; Gatley, S.; Campbell, B.R. Repurposing an erstwhile cancer drug: A quantitative and therapeutic evaluation of alternative nanosystems for the delivery of colchicine to solid tumors. J. Cancer Sci. Ther. 2014, 6, 236-246. [CrossRef]

57. Tortorici, M.A.; Skledar, S.; Barnes, B.; Wasko, M.C. Promoting the safe use of intravenous colchicine. Am. J. Health Syst. Pharm. 2004, 61, 2496-2501. [PubMed]

58. Deveaux, M.; Hubert, N.; Demarly, C. Colchicine poisoning: Case report of two suicides. Forensic. Sci. Int. 2004, 143, 219-222. [CrossRef] [PubMed]

59. Fernandez, S.; Castro, P.; Nogue, S.; Nicolas, J.M. Refractory shock and severe leukopenia with multisystemic organ failure due to colchicine intentional overdose. Med. Clin. 2014, 143, 140.

60. Suh, J.; Choy, K.-L.; Lai, S.K.; Suk, J.S.; Tang, B.C.; Prabhu, S.; Hanes, J. Pegylation of nanoparticles improves their cytoplasmic transport. Int. J. Nanomed. 2007, 2, 735-741.

61. Lu, Y.; Li, C.-M.; Wang, Z.; Ross, C.R.; Chen, J.; Dalton, J.T.; Li, W.; Miller, D.D. Discovery of 4-substituted methoxybenzoyl-aryl-thiazole as novel anticancer agents: Synthesis, biological evaluation, and structure-activity relationships. J. Med. Chem. 2009, 52, 1701-1711. [CrossRef] [PubMed] 
62. Lu, Y.; Li, C.-M.; Wang, Z.; Chen, J.; Mohler, M.L.; Li, W.; Dalton, J.T.; Miller, D.D. Design, synthesis, and sar studies of 4-substituted methoxylbenzoyl-aryl-thiazoles analogues as potent and orally bioavailable anticancer agents. J. Med. Chem. 2011, 54, 4678-4693. [CrossRef] [PubMed]

63. Sengupta, S.; Eavarone, D.; Capila, I.; Zhao, G.; Watson, N.; Kiziltepe, T.; Sasisekharan, R. Temporal targeting of tumour cells and neovasculature with a nanoscale delivery system. Nature 2005, 436, 568-572. [CrossRef] [PubMed]

64. Li, X.; Wu, M.; Pan, L.; Shi, J. Tumor vascular-targeted co-delivery of anti-angiogenesis and chemotherapeutic agents by mesoporous silica nanoparticle-based drug delivery system for synergetic therapy of tumor. Int. J. Nanomed. 2016, 11, 93-105. [CrossRef] [PubMed]

65. Sumer Bolu, B.; Manavoglu Gecici, E.; Sanyal, R. Combretastatin A-4 conjugated antiangiogenic micellar drug delivery systems using dendron-polymer conjugates. Mol. Pharm. 2016, 13, 1482-1490. [CrossRef] [PubMed]

66. Houghton, P.J.; Kurmasheva, R.T.; Kolb, E.A.; Gorlick, R.; Maris, J.M.; Wu, J.; Tong, Z.; Arnold, M.A.; Chatterjee, M.; Williams, T.M.; et al. Initial testing (stage 1) of the tubulin binding agent nanoparticle albumin-bound (nab) paclitaxel (Abraxane ${ }^{\circledR}$ ) by the pediatric Preclinical Testing Program (PPTP). Pediatr. Blood Cancer 2015, 62, 1214-1221. [CrossRef] [PubMed]

67. Desai, N.; Trieu, V.; Damascelli, B.; Soon-Shiong, P. Sparc expression correlates with tumor response to albumin-bound paclitaxel in head and neck cancer patients. Transl. Oncol. 2009, 2, 59-64. [CrossRef] [PubMed]

68. De Leon, M.C.B.; Bolla, S.; Greene, B.; Hutchinson, L.; Del Priore, G. Successful treatment with nab-paclitaxel after hypersensitivity reaction to paclitaxel and docetaxel. Gynecol. Oncol. Case Rep. 2013, 5, 70-71. [CrossRef] [PubMed]

69. Miele, E.; Spinelli, G.P.; Miele, E.; Tomao, F.; Tomao, S. Albumin-bound formulation of paclitaxel (Abraxane ${ }^{\circledR}$ ABI-007) in the treatment of breast cancer. Int. J. Nanomed. 2009, 4, 99-105.

70. Kretschmar, C.S.; Kletzel, M.; Murray, K.; Thorner, P.; Joshi, V.; Marcus, R.; Smith, E.I.; London, W.B.; Castleberry, R. Response to paclitaxel, topotecan, and topotecan-cyclophosphamide in children with untreated disseminated neuroblastoma treated in an upfront phase II investigational window: A pediatric oncology group study. J. Clin. Oncol. 2004, 22, 4119-4126. [CrossRef] [PubMed]

71. Doz, F.; Gentet, J.C.; Pein, F.; Frappaz, D.; Chastagner, P.; Moretti, S.; Vassal, G.; Arditti, J.; Tellingen, O.V.; Iliadis, A.; et al. Phase I trial and pharmacological study of a 3-hour paclitaxel infusion in children with refractory solid tumours: A SFOP study. Br. J. Cancer 2001, 84, 604-610. [CrossRef] [PubMed]

72. Kolb, E.A.; Gorlick, R.; Reynolds, C.P.; Kang, M.H.; Carol, H.; Lock, R.; Keir, S.T.; Maris, J.M.; Billups, C.A.; DesJardins, C.; et al. Initial testing (stage 1) of eribulin, a novel tubulin binding agent, by the pediatric preclinical testing program. Pediatr. Blood Cancer 2013, 60, 1325-1332. [CrossRef] [PubMed]

73. Wong, H.; Choo, E.F.; Alicke, B.; Ding, X.; La, H.; McNamara, E.; Theil, F.-P.; Tibbitts, J.; Friedman, L.S.; Hop, C.E.C.A.; et al. Antitumor activity of targeted and cytotoxic agents in murine subcutaneous tumor models correlates with clinical response. Clin. Cancer Res. 2012, 18, 3846-3855. [CrossRef] [PubMed]

74. Desai, N.P.; Trieu, V.; Hwang, L.Y.; Wu, R.; Soon-Shiong, P.; Gradishar, W.J. Improved effectiveness of nanoparticle albumin-bound (nab) paclitaxel versus polysorbate-based docetaxel in multiple xenografts as a function of HER2 and SPARC status. Anti-Cancer Drugs 2008, 19, 899-909. [CrossRef] [PubMed]

75. Mielke, S.; Sparreboom, A.; Steinberg, S.M.; Gelderblom, H.; Unger, C.; Behringer, D.; Mross, K. Association of paclitaxel pharmacokinetics with the development of peripheral neuropathy in patients with advanced cancer. Clin. Cancer Res. 2005, 11, 4843-4850. [CrossRef] [PubMed]

76. Mielke, S.; Sparreboom, A.; Mross, K. Peripheral neuropathy: A persisting challenge in paclitaxel-based regimes. Eur. J. Cancer 2006, 42, 24-30. [CrossRef] [PubMed]

77. Knemeyer, I.; Wientjes, G.M.; Au, L.S.J. Cremophor reduces paclitaxel penetration into bladder wall during intravesical treatment. Cancer Chemother. Pharmacol. 1999, 44, 241-248. [CrossRef] [PubMed]

78. Gradishar, W.J.; Tjulandin, S.; Davidson, N.; Shaw, H.; Desai, N.; Bhar, P.; Hawkins, M.; O'Shaughnessy, J. Phase III trial of nanoparticle albumin-bound paclitaxel compared with polyethylated castor oil-based paclitaxel in women with breast cancer. J. Clin. Oncol. 2005, 23, 7794-7803. [CrossRef] [PubMed]

79. Kundranda, M.N.; Niu, J. Albumin-bound paclitaxel in solid tumors: Clinical development and future directions. Drug Des. Dev. Ther. 2015, 9, 3767-3777. [CrossRef] [PubMed] 
80. Gupta, N.; Hatoum, H.; Dy, G.K. First line treatment of advanced non-small-cell lung cancer-Specific focus on albumin bound paclitaxel. Int. J. Nanomed. 2014, 9, 209-221.

81. Von Hoff, D.D.; Ervin, T.; Arena, F.P.; Chiorean, E.G.; Infante, J.; Moore, M.; Seay, T.; Tjulandin, S.A.; Ma, W.W.; Saleh, M.N.; et al. Increased survival in pancreatic cancer with nab-paclitaxel plus gemcitabine. N. Engl. J. Med. 2013, 369, 1691-1703. [CrossRef] [PubMed]

82. Bansal, A.; Kapoor, D.N.; Kapil, R.; Chhabra, N.; Dhawan, S. Design and development of paclitaxel-loaded bovine serum albumin nanoparticles for brain targeting. Acta Pharm. 2011, 61, 141-156. [CrossRef] [PubMed]

83. Wang, B.; Lv, L.; Wang, Z.; Jiang, Y.; Lv, W.; Liu, X.; Wang, Z.; Zhao, Y.; Xin, H.; Xu, Q. Improved anti-glioblastoma efficacy by IL-13R $\alpha 2$ mediated copolymer nanoparticles loaded with paclitaxel. Sci. Rep. 2015, 5. [CrossRef] [PubMed]

84. Yi, X.; Lian, X.; Dong, J.; Wan, Z.; Xia, C.; Song, X.; Fu, Y.; Gong, T.; Zhang, Z. Co-delivery of pirarubicin and paclitaxel by human serum albumin nanoparticles to enhance antitumor effect and reduce systemic toxicity in breast cancers. Mol. Pharm. 2015, 12, 4085-4098. [CrossRef] [PubMed]

85. Tozer, G.M.; Kanthou, C.; Baguley, B.C. Disrupting tumour blood vessels. Nat. Rev. Cancer 2005, 5, $423-435$. [CrossRef] [PubMed]

86. Kanthou, C.; Tozer, G.M. Selective destruction of the tumour vasculature by targeting the endothelial cytoskeleton. Drug Discov. Today. Ther. Strateg. 2007, 4, 237-243. [CrossRef]

87. Siemann, D.W.; Bibby, M.C.; Dark, G.G.; Dicker, A.P.; Eskens, F.A.L.M.; Horsman, M.R.; Marmé, D.; LoRusso, P.M. Differentiation and definition of vascular-targeted therapies. Clin. Cancer Res. 2005, 11, 416-420. [PubMed]

88. Carmeliet, P. Angiogenesis in life, disease and medicine. Nature 2005, 438, 932-936. [CrossRef] [PubMed]

89. El-Kenawi, A.E.; El-Remessy, A.B. Angiogenesis inhibitors in cancer therapy: Mechanistic perspective on classification and treatment rationales. Br. J. Pharmacol. 2013, 170, 712-729. [CrossRef] [PubMed]

90. Vasudev, N.S.; Reynolds, A.R. Anti-angiogenic therapy for cancer: Current progress, unresolved questions and future directions. Angiogenesis 2014, 17, 471-494. [CrossRef] [PubMed]

91. Romagnoli, R.; Baraldi, P.G.; Salvador, M.K.; Prencipe, F.; Lopez-Cara, C.; Schiaffino Ortega, S.; Brancale, A.; Hamel, E.; Castagliuolo, I.; Mitola, S.; et al. Design, synthesis, in vitro, and in vivo anticancer and antiangiogenic activity of novel 3-arylaminobenzofuran derivatives targeting the colchicine site on tubulin. J. Med. Chem. 2015, 58, 3209-3222. [CrossRef] [PubMed]

92. Porcù, E.; Viola, G.; Bortolozzi, R.; Persano, L.; Mitola, S.; Ronca, R.; Presta, M.; Romagnoli, R.; Baraldi, P.G.; Basso, G. TR-644 a novel potent tubulin binding agent induces impairment of endothelial cells function and inhibits angiogenesis. Angiogenesis 2013, 16, 647-662. [CrossRef] [PubMed]

93. Ganguly, A.; Cabral, F.; Yang, H.; Patel, K.D. Peloruside a is a microtubule-stabilizing agent with exceptional anti-migratory properties in human endothelial cells. Oncoscience 2015, 2, 585-595. [CrossRef] [PubMed]

94. Broggini-Tenzer, A.; Sharma, A.; Nytko, K.J.; Bender, S.; Vuong, V.; Orlowski, K.; Hug, D.; O’Reilly, T.; Pruschy, M. Combined treatment strategies for microtubule stabilizing agent-resistant tumors. J. Natl. Cancer Inst. 2015, 107. [CrossRef] [PubMed]

95. Chan, A.; Singh, A.J.; Northcote, P.T.; Miller, J.H. Inhibition of human vascular endothelial cell migration and capillary-like tube formation by the microtubule-stabilizing agent peloruside A. Investig. New Drugs 2015, 33, 564-574. [CrossRef] [PubMed]

96. Bocci, G.; Di Paolo, A.; Danesi, R. The pharmacological bases of the antiangiogenic activity of paclitaxel. Angiogenesis 2013, 16, 481-492. [CrossRef] [PubMed]

97. Lu, H.; Murtagh, J.; Schwartz, E.L. The microtubule binding drug laulimalide inhibits vascular endothelial growth factor-induced human endothelial cell migration and is synergistic when combined with docetaxel (taxotere). Mol. Pharmacol. 2006, 69, 1207-1215. [CrossRef] [PubMed]

98. Zhu, S.; Kisiel, W.; Lu, Y.J.; Petersen, L.C.; Ndungu, J.M.; Moore, T.W.; Parker, E.T.; Sun, A.; Liotta, D.C.; El-Rayes, B.F.; et al. Tumor angiogenesis therapy using targeted delivery of paclitaxel to the vasculature of breast cancer metastases. J. Drug Deliv. 2014, 2014. [CrossRef] [PubMed]

99. Lin, C.M.; Singh, S.B.; Chu, P.S.; Dempcy, R.O.; Schmidt, J.M.; Pettit, G.R.; Hamel, E. Interactions of tubulin with potent natural and synthetic analogs of the antimitotic agent combretastatin: A structure-activity study. Mol. Pharmacol. 1988, 34, 200-208. [PubMed]

100. Massarotti, A.; Coluccia, A.; Silvestri, R.; Sorba, G.; Brancale, A. The tubulin colchicine domain: A molecular modeling perspective. ChemMedChem 2012, 7, 33-42. [CrossRef] [PubMed] 
101. Srivastava, V.; Negi, A.S.; Kumar, J.K.; Gupta, M.M.; Khanuja, S.P.S. Plant-based anticancer molecules: A chemical and biological profile of some important leads. Bioorg. Med. Chem. 2005, 13, 5892-5908. [CrossRef] [PubMed]

102. Horner, S.A.; Gould, S.; Noakes, J.P.; Rattray, N.J.; Allen, S.L.; Zotova, E.; Arezzo, J.C. Lack of neurotoxicity of the vascular targeting agent ZD6126 following repeated i.v. Dosing in the rat. Mol. Cancer Ther. 2004, 3, 783-791. [PubMed]

103. Pilat, M.J.; LoRusso, P.M. Vascular disrupting agents. J. Cell. Biochem. 2006, 99, 1021-1039. [CrossRef] [PubMed]

104. Lee, J.; Bae, S.; Lee, S.-H.; Choi, H.; Kim, Y.H.; Kim, S.J.; Park, G.T.; Moon, S.K.; Kim, D.-H.; Lee, S.; et al. Discovery of a potent tubulin polymerization inhibitor: Synthesis and evaluation of water-soluble prodrugs of benzophenone analog. Bioorg. Med. Chem. Lett. 2010, 20, 6327-6330. [CrossRef] [PubMed]

105. Lee, J.; Kim, S.J.; Choi, H.; Kim, Y.H.; Lim, I.T.; Yang, H.-M.; Lee, C.S.; Kang, H.R.; Ahn, S.K.; Moon, S.K.; et al. Identification of CKD-516: A potent tubulin polymerization inhibitor with marked antitumor activity against murine and human solid tumors. J. Med. Chem. 2010, 53, 6337-6354. [CrossRef] [PubMed]

106. Kim, K.W.; Lee, J.M.; Jeon, Y.S.; Lee, I.J.; Choi, Y.; Park, J.; Kiefer, B.; Kim, C.; Han, J.K.; Choi, B.I. Vascular disrupting effect of CKD-516: Preclinical study using DCE-MRI. Investig. New Drugs 2013, 31, 1097-1106. [CrossRef] [PubMed]

107. Oh, D.-Y.; Kim, T.-M.; Han, S.-W.; Shin, D.-Y.; Lee, Y.G.; Lee, K.-W.; Kim, J.H.; Kim, T.-Y.; Jang, I.-J.; Lee, J.-S.; et al. Phase i study of CKD-516, a novel vascular disrupting agent, in patients with advanced solid tumors. Cancer Res. Treat. 2016, 48, 28-36. [CrossRef] [PubMed]

108. Kremmidiotis, G.; Leske, A.F.; Lavranos, T.C.; Beaumont, D.; Gasic, J.; Hall, A.; O'Callaghan, M.; Matthews, C.A.; Flynn, B. BNC105: A novel tubulin polymerization inhibitor that selectively disrupts tumor vasculature and displays single-agent antitumor efficacy. Mol. Cancer Ther. 2010, 9, 1562-1573. [CrossRef] [PubMed]

109. Rischin, D.; Bibby, D.C.; Chong, G.; Kremmidiotis, G.; Leske, A.F.; Matthews, C.A.; Wong, S.S.; Rosen, M.A.; Desai, J. Clinical, pharmacodynamic, and pharmacokinetic evaluation of BNC105P: A phase I trial of a novel vascular disrupting agent and inhibitor of cancer cell proliferation. Clin. Cancer Res. 2011, 17, 5152-5160. [CrossRef] [PubMed]

110. Yakushiji, F.; Tanaka, H.; Muguruma, K.; Iwahashi, T.; Yamazaki, Y.; Hayashi, Y. Water-soluble prodrug of antimicrotubule agent plinabulin: Effective strategy with click chemistry. Chem. Eur. J. 2011, 17, 12587-12590. [CrossRef] [PubMed]

111. Millward, M.; Mainwaring, P.; Mita, A.; Federico, K.; Lloyd, G.K.; Reddinger, N.; Nawrocki, S.; Mita, M.; Spear, M.A. Phase 1 study of the novel vascular disrupting agent plinabulin (NPI-2358) and docetaxel. Investig. New Drugs 2012, 30, 1065-1073. [CrossRef] [PubMed]

112. Burns, C.J.; Harte, M.F.; Bu, X.; Fantino, E.; Joffe, M.; Sikanyika, H.; Su, S.; Tranberg, C.E.; Wilson, N.; Charman, S.A.; et al. Discovery of CYT997: A structurally novel orally active microtubule targeting agent. Bioorg. Med. Chem. Lett. 2009, 19, 4639-4642. [CrossRef] [PubMed]

113. Burns, C.J.; Fantino, E.; Powell, A.K.; Shnyder, S.D.; Cooper, P.A.; Nelson, S.; Christophi, C.; Malcontenti-Wilson, C.; Dubljevic, V.; Harte, M.F.; et al. The microtubule depolymerizing agent CYT997 causes extensive ablation of tumor vasculature in vivo. J. Pharmacol. Exp. Ther. 2011, 339, 799-806. [CrossRef] [PubMed]

114. Monaghan, K.; Khong, T.; Smith, G.; Spencer, A. CYT997 causes apoptosis in human multiple myeloma. Investig. New Drugs 2011, 29, 232-238. [CrossRef] [PubMed]

115. Kasibhatla, S.; Baichwal, V.; Cai, S.X.; Roth, B.; Skvortsova, I.; Skvortsov, S.; Lukas, P.; English, N.M.; Sirisoma, N.; Drewe, J.; et al. MPC-6827: A small-molecule inhibitor of microtubule formation that is not a substrate for multidrug resistance pumps. Cancer Res. 2007, 67, 5865-5871. [CrossRef] [PubMed]

116. Grossmann, K.F.; Colman, H.; Akerley, W.A.; Glantz, M.; Matsuoko, Y.; Beelen, A.P.; Yu, M.; De Groot, J.F.; Aiken, R.D.; Olsen, J.J.; et al. Phase I trial of verubulin (MPC-6827) plus carboplatin in patients with relapsed glioblastoma multiforme. J. Neurooncol. 2012, 110, 257-264. [CrossRef] [PubMed]

117. Tsimberidou, A.-M.; Akerley, W.; Schabel, M.C.; Hong, D.S.; Uehara, C.; Chhabra, A.; Warren, T.; Mather, G.G.; Evans, B.A.; Woodland, D.P.; et al. Phase I clinical trial of MPC-6827 (Azixa), a microtubule destabilizing agent, in patients with advanced cancer. Mol. Cancer Ther. 2010, 9, 3410-3419. [CrossRef] [PubMed] 
118. Mahal, K.; Resch, M.; Ficner, R.; Schobert, R.; Biersack, B.; Mueller, T. Effects of the tumor-vasculaturedisrupting agent verubulin and two heteroaryl analogues on cancer cells, endothelial cells, and blood vessels. ChemMedChem 2014, 9, 847-854. [CrossRef] [PubMed]

119. Patil, S.A.; Patil, R.; Pfeffer, L.M.; Miller, D.D. Chromenes: Potential new chemotherapeutic agents for cancer. Future Med. Chem. 2013, 5, 1647-1660. [CrossRef] [PubMed]

120. Banerjee, S.; Wang, J.; Pfeffer, S.; Ma, D.; Pfeffer, L.; Patil, S.; Li, W.; Miller, D. Design, synthesis and biological evaluation of novel $5 \mathrm{H}$-chromenopyridines as potential anti-cancer agents. Molecules 2015, 20, 17152-17165. [CrossRef] [PubMed]

(c)

(C) 2016 by the authors; licensee MDPI, Basel, Switzerland. This article is an open access article distributed under the terms and conditions of the Creative Commons Attribution (CC-BY) license (http://creativecommons.org/licenses/by/4.0/). 